\title{
Biofuel Supply Chain Risk Mitigation Strategy Framework: Expert Interview Based Approach
}

\author{
Tedy Wachyudi (iD, Arief Daryanto (iD), Machfud Machfud (iD, Yandra Arkeman (iD \\ School of Business, IPB University (Indonesia) \\ mytedyw@gmail.com,adaryant@icloud.com,mfd@indo.net.id,yandra.arkeman@gmail.com
}

Received: Desember 2018

Accepted: July 2019

\begin{abstract}
:
Purpose: The purpose of this case study is to develop and framework the biodiesel downstream supply chain characteristics and risk mitigation strategies.

Design/methodology/approach: This study employs an expert interview-based approach as a qualitative approach with a multi-perspectives view.

Findings: There are varying strategies among perspectives, such as perspectives of organization and business types, stakeholder types, times and methods. These also show that business strategies of collaborative, coordinative, and cooperative arise as alternative strategies for each perspective and each level of stakeholder. Those business strategies may apply in a variety of operational strategies linking them through an energy security framework element, as a company's competitive priorities.
\end{abstract}

Research limitations/implications: The research scope includes only a certain area of the country's territory and the target company's supply chain areas of activity. The research method includes only internal stakeholders and experts as respondents and data sources. The level of analysis was only at a corporate level in the corporate case study context. The research also targets only downstream activities of biodiesel supply chain context. The interview-based approach as a qualitative approach faces some subjectivity challenges among respondents.

Practical implications: The research result provides some positive implications for business practice, including how to minimize the impact of supply chain risk on a company's business activities and performance, how supply chain experts and practitioners used risk mitigation practices, how to formulate strategic plans to minimize the impact of supply chain risk and enhance the effectivity and sustainability of the supply chain activities.

Social implications: The implication for business practice was that a company's leaders implemented supply chain risk mitigation strategies that provide positive impacts on the more valuable relationship among supply chain actors and stakeholders.

Originality/value: The first, is an activities area and operational schemes-based of biodiesel supply chain point of view. The second, is a multi-perspectives-based biodiesel supply chain characteristics framework. The third, is an energy security framework-based biodiesel risk mitigation strategies framework.

Keywords: supply chain, risk mitigation strategy, biofuel, expert interview-based approach 


\section{To cite this article:}

Wachyudi, T., Daryanto, A., Machfud, M., \& Arkeman, Y. (2020). Biofuel Supply Chain Risk Mitigation Strategy Framework: Expert Interview Based Approach. Journal of Industrial Engineering and Management, 13(1), 179-194. https://doi.org/10.3926/jiem.2812

\section{Introduction}

Organizations can use supply chain strategies to gain a competitive advantage for the supply chain. A competitive advantage can be achieved by means of low cost or by means of differentiation. However, organizations have to implement the correct supply chain strategy (Nel \& Badenhorst-Weiss, 2011). In the globalize market, supply chain disruption is a problem, but it is also increasingly significant for ensuring the business continuity. In some organizations, it has become a significant concerned issue (Clark, 2012).

A business operation needs a risk assessment, so the supply chain risk assessment is essential to business operation (Clark, 2012). Determining how the organizations are managing their supply chain drivers is the way to analyze the differences between supply chain strategies implied by literature and those implemented by selected organizations (Nel \& Weiss, 2011). Because of unforeseen circumstances, managing supply chains in a competitive and turbulent market is challenging (Clark, 2012). There is an opportunity for joint problem-solving across supply chain partners to implement best practices, so the supply chain authorities can help to increase the efficiency of physical, informational, and financial flows for the supply chain (Wakolbinger \& Cruz, 2011).

The supply chain authorities have focused on the extended supply chain for information sharing. This is vital for identifying and assessing potential supply chain disruptions (Wakolbinger \& Cruz, 2011). The failure of information exchange may potentially occur in disruptions for all partnering companies whose searching for and extracting raw materials in the upstream context and actual sale of that product to other businesses, or private individuals in the downstream context (Bouncken, 2011).

To reduce the supply chain uncertainties, the supply chain authorities are taking risk-adjusted methods by looking at supply chains to improve fundamental areas in the downstream and upstream of the chain (Clark, 2012; Pettit, Croxton \& Fiksel, 2013). The supply chain authorities need to develop techniques to minimize the effect of such disruptions, including implementing supply chain strategies (Carvalho, Maleki \& Cruz-Machado, 2012; Wieland \& Wallenburg, 2012). Supply chain experts are using supply chain performance, and competitive strategies to reduce costs and to focus on core value-adding activities to address complexities (Sharma \& Bhat, 2011).

Since supply chain operation is an essential aspect of customer satisfaction in a dynamic environment, procedures for managing supply chain risk are necessary to support both long-term and short-term strategic decision-making (Yao, 2013). Managers are adopting risk-mitigating strategies within the supply chain because of the increasing complexity and disruptions in the system (Wakolbinger \& Cruz, 2011).

The general business problem is the failure to manage supply chain disruptions, which result in economic and financial losses to stakeholders. The specific business problem was that some supply chain managers are unaware about how to develop strategies to mitigate the impacts associated with supply chain risk (Opata, 2015). Due to the global financial crisis, supply chain managers have increased implementation, cost-saving, and cost-cutting strategies to avoid supply chain disruptions (Gurnani, Ray \& Yunzeng, 2011). The disruptions were detrimental to operational performance due to the associated loss of profitability, shareholder wealth, and organizational reputation (Schotter \& Thi My, 2013). The estimated cost of one supply chain disruption was $\$ 10$ million (Wildgoose, Brennan \& Thompson, 2012).

The study targets the biodiesel supply chain activities within the areas of Pertamina's Supply and Distribution Region III which includes the areas of: Jakarta (The Capital of Indonesia), West Java and Banten. There are 8 fuel terminal units with a 1.5 million kilo liters of fuel storage capacity which are supported by vary and related infrastructures (such as vessels, jetties, line-pipes, tank trucks, fuel stations) operated within the operational areas 
(Pertamina, 2018). The operation supplies and distributes a 15.5 million kilo liters of fuel per year to service a huge number of both retail and industrial customers in the related areas (Interviews, 2018).

Organizations implement specific strategies to gain a competitive advantage by means of a cost advantage or differentiation in some form of value advantage (Christopher, 2005). It is thus essential that organizations identify and implement the fit supply chain strategy.

With reference to the research background, the research questions are: (1) What are the resumes of the target company's biodiesel downstream supply chain risk map, based on the previous research results? (2) What are the characteristics of the existing biodiesel supply chain of the target company? (3) What is the risk mitigation strategy framework to enhance the effectivity and the sustainability of the biodiesel supply chain?

The purpose of this qualitative case study is to map the characteristics of the supply chain and to propose an alternative strategies framework for mitigating the related supply chain risk mitigation in the context of the biodiesel downstream supply chain within the target company. Those aims to reduce the impact of risks in the supply chain. The research is a case study design research with the level of analysis at corporate level. The targeted population consisted of risk and supply chain experts in an Indonesian oil and gas state owned enterprise. The study employs semi-structured interviews and related document reviews to explore risks and risk mitigations within the target company's biodiesel supply chain.

This study covers the biodiesel downstream supply chain, including the activities of supply, process and demand of retail biodiesel. The research takes place at Supply \& Distribution Region III PT Pertamina (Persero) which covers the following three main areas of: Jakarta (the capital of Indonesia), West Java Province and Banten Province. There are a number of reasons and considerations for choosing the mentioned research areas, such as: its locations' strategical aspect, its commercial and market complexity aspect, and its operational complexity aspect. The research focuses on the study of retail biodiesel supply chain risks in the downstream operation perspective.

Supply chain risks exists at both upstream side and downstream side of the business (Ouabouch \& Pache, 2014; Jüttner, 2005). For some reasons, risk is often perceived as a non-critical issue (Pritchard, 2015). In other side, there was a viewer study $(1.2 \%)$ of risk management-based supply chain (Defee, Williams, Randall \& Thomas, 2010). The existence of a more holistic view and study of the mentioned risk management are still limited.

This study will propose novelties. The first, is an activities and operational schemes-based biodiesel supply chain point of view. The second, is a multi-perspectives-based biodiesel supply chain characteristics framework. The third, is an energy security framework-based biodiesel risk mitigation strategies framework.

The research results provide some positive implications for business practice. Those results involve how to minimize the impact of supply chain risk on a company's business activities and performance. The research was indicative of how supply chain experts and practitioners used risk mitigation practices. Experts and practitioners can apply the principles and the findings from this study to formulate strategic plans to minimize the impact of supply chain risk and enhance the effectivity and sustainability of the supply chain activities. The implication for business practice was that company leaders implemented supply chain risk mitigation strategies that provide positive impacts on the more valuable relationship among supply chain actors and stakeholders.

In this paper we begin by discussing the concept and the urgency of supply chain and risk management. We then describe methodology and research steps, including the characteristic of target experts and the process of expert interviews. The further parts of the paper provide risk management cycles application within the research. Finally, we proposed a framework of the biodiesel supply chain strategy alternatives which based on the supply chain areas of operation and the company's competitive priorities. We conclude by noting implications and directions for further research.

\section{Supply Chain Risk Mitigation Strategy}

Supply chain management (SCM) has been defined in vary definitions. One of those define that SCM is involving how to manage complex flow of related elements across multiples functional areas, both within and 
among related companies. The elements consist of information, materials, and money. Those to achieve total system performance rather than optimization of a single phase of supply chain (Helo \& Szekely, 2005). Mentzer (2001), defines SCM as the systemic, strategic coordination of the traditional business functions across businesses within the supply chain.

This paper discusses about the biofuel supply chain case study, especially in the context of biodiesel downstream supply chain and supply chain risks. Biofuels are fuels produced from biological products, including biomass, liquid fuels and biogases. In the context of biofuel supply chain, some research has been done. chain. Based on the previous research, the proposed biofuel supply chain and market model is based on a few simplifying assumptions which is provide rooms for future research directions (Zhang, 2013).

Companies have been facing challenges related to their typical stakeholders, in the interest contexts of their profitability. Challenges also comes from state regulatory authorities, non-governmental organizations for their social and environmental profiles, and also from consumers. In the context of their goals and objectives, those are not necessarily the same as the companies' and many times they are quite different (Wassenhove \& Besiou, 2013).

There always be inherent risks within the supply chain. A supply chain design has to involve sufficient inherent risks consideration within, otherwise it will face a high probability of failure (Faisal, Banwet \& Shankar, 2006). Many different forms of supply chain risks can be classified according to how their realization impacts on a business and its environment (Harland, Brenchley \& Walker, 2003). To be succeed, companies have to identify and develop contingency plans for existed risks, which related to both the organization's internal and external (Zolkos, 2003). Improved understanding of supply chain risks provides benefits and helps for better decisions and lower risks of both a single organization and the whole network (Hallikas, Karvonen, Pulkkinen, Virolainen \& Tuominen, 2004).

Contemporary research recommends a lean, agile or leagile supply chain design (Christopher \& Towill, 2000). Weaver (2011) proposed a C3 framework which consist of: coordination, cooperation and collaboration to define company's supply chain strategy to approach their external partners. In-line with this framework, future supply chain partnership should be more coordinative, cooperative or collaborative in nature and behavior.

\section{Methodology}

This research applies an expert interviews-based approach in supply chain risk management in order to frameworks biodiesel supply chain risk mitigation strategies and increase the effectivity and the sustainability of the supply chain. This study employs a qualitative approach with a multi-perspectives view. Frels and Onwuegbuzie (2013) stated that a qualitative method used to explore the different risk issues relating to the supply chain. Yin (2012) stated that qualitative method is useful when the researcher does not identify key variables. Descriptive and explanatory approach applies in this research. Descriptive approach includes a number of literature studies and secondary data analysis. Explanatory approach includes number of expert surveys and interviews.

The research boundary of the study includes the activities of downstream biodiesel supply chain at PT Pertamina (Persero). PT Pertamina (Persero) is an Indonesia state owned enterprise focused in energy business, especially in oil and gas businesses, which in this paper will be stated as Pertamina. The research takes place at Pertamina Supply \& Distribution Region III, including the areas of: Jakarta as the capital of Indonesia, West Java Province and Banten Province. The period of research was from March 2018 until November 2018. All of the research activities were conducted in Indonesia.

\subsection{Research Steps}

The primary and secondary data were collected from data sources. The data are from both internal and external sources of the target company. The list of the research steps, data sources and data collection methods as shown in Table 1. 


\begin{tabular}{|c|l|l|l|}
\hline No. & \multicolumn{1}{|c|}{ Research Steps } & \multicolumn{1}{c|}{ Data Sources } & \multicolumn{1}{c|}{ Methods } \\
\hline 1 & Author's previous research result reidentification & Secondary Data & Literature Review + Interview \\
\hline 2 & Previous research result post-analysis & Secondary Data & Literature Review + Interview \\
\hline 3 & Expert interviews and validations & Interviewed Experts & Interview \\
\hline 4 & Result analysis & Primary + Secondary Data & Literature Review \\
\hline 5 & Alternativa strategies frameworking & Primary + Secondary Data & Literature Review + Interview \\
\hline
\end{tabular}

Table 1. List of research steps, data sources and methods

Supported by observations and surveys, expert interviews were employed as a main data collection method. The list of surveyed and interviewed experts of the target company supply chain as shown in Table 2. The selected interviewees are the related and the strategical stakeholders because of their fulfilled qualifications of expertise, legitimation and access to the supply chain policies and activities. Semi-structured questionnaire takes place in applying surveys and interviews to the respondents and interviewees. The level of analysis is at a corporate level.

\subsection{Expert Characteristics}

In the context of management, the experts are differentiated from beginners through their experiments and tacit knowledges (Tsoukas, 2009). In this study, experts are defined as those persons in charge of job activities, authorities, is knowledgeable and experienced as related to the fuel supply chain management and activities within the target company. The experts must have related work experiences of 15 years and above. He or she must have been responsible for, and in charge of authorized persons in the target company.

\subsection{Expert Interviews}

Interviews were conducted through face to face interviews at the target expert locations and indirect interviews via telecommunication facilities media between interviewer and target interviewed experts at their work location. The researcher and author act as the interviewer. Both interview schemes apply the same semi-structured questionnaire templates. The duration of interview was 45 to 60 minutes for each interviewed expert.

The interviews involved supply chain experts within the target company which included different internal stakeholder levels such as visionary leader, strategic leader and operations leader. They had work experiences of more than 15 years to more than 25 years in the target company. Their current positions are all in the supply chain related positions within the target companies and located within the target research areas.

The results of the interview are an important input for the identification, selection and placement decisions to frameworks risk mitigation strategy alternatives. Its accuracy was constantly monitored.

\begin{tabular}{|c|l|l|l|c|}
\hline No. & \multicolumn{1}{|c|}{ Expert Levels } & \multicolumn{1}{|c|}{ Positions } & \multicolumn{1}{|c|}{ Locations } & Year of Experiences \\
\hline 1 & Visionary Leader & Director & LSI Directorate, H. O. Jakarta & $>25$ \\
\hline 2 & Strategic Leader & Vice President & S\&D Division, H.O. Jakarta & $>25$ \\
\hline 3 & Operation Leader & Region Manager & S\&D Region III, Jakarta & $>25$ \\
\hline 4 & Operation Leader & Operation Head & Fuel Terminal 1 + 2 (Group), Jakarta & $>15$ \\
\hline 5 & Operation Leader & Operation Head & Fuel Terminal 3, Cilegon - Banten & $>20$ \\
\hline 6 & Operation Leader & Operation Head & Fuel Terminal 4, Indramayu - West Java & $>20$ \\
\hline 7 & Operation Leader & Operation Head & Fuel Terminal 5, Cikampek - West Java & $>$ \\
\hline 8 & Operation Leader & Operation Head & Fuel Terminal 6 + 7 (Group), Bandung - West Java & \\
\hline 9 & Operation Leader & Operation Head & Fuel Terminal 8, Tasikmalaya - West Java & \\
\hline
\end{tabular}

Table 2. List of interviewed experts 


\section{Result and Discussion}

In reference to the author's previous research results there were a number of secondary data results. Figures 1 and 2 describes the biodiesel supply chain business process within the target company. Tables 3 and 4 show the list of supply chain risk scores gained from data collection and calculations using a Failure Mode and Effect Analysis (FMEA) as an analytical tool. The data within the Tables describes that there are three highest scores of supply chain risks. Two of them are in supply risks with the Risk Priority Number (RPN) scores of 72 for regulation risk and 48 for product arrival schedule unfit risk. While another one is in process risk with the RPN score of 48 for transport facilities availability and reliability risk. Those all describe the risk priority perceptions and preferences among stakeholder levels and locations as well.

The target company downstream fuel supply and distribution activities involved at least 109 fuel depot units which spread among 8 fuel supply and distribution regions which cover 5 bigger islands (Sumatera, Jawa, Kalimantan, Sulawesi and Papua) and hundreds up to thousands smaller surrounding islands. A huge number of infrastructures and facilities involved, including more than 2,000 fuel tank trucks, more than 250 vessels (tankers), more than 300 jetties, more than 1,500 kilo meters of pipe-line facilities and a number of air-transport units for servicing both cities and remote areas.

The target research area was Pertamina's Supply \& Distribution Region III. The biodiesel supply chain activities are involved in a number of related determinants and issues. There are: 8 fuel terminal units, 1.5 million kilo liters of fuel storages capacity, 15.5 million kilo liters of fuel supplies and distributes per year, 5 locations of fuel loading/discharging ports, 17 jetties, 600 fuel tank truck units, 15 vessel (tanker) units, 960 kilo meters of pipe-line facilities, 2,332 retail customers, 336 industrial customers and 169 special customers.

It was in 2006 the application of biodiesel became mandatory in the Indonesian domestic market. There have been such dynamics and progress from 2006 up to now. Such related opportunities and threats or risks arise within, including such opportunities and threats or risks of biodiesel supply chain activities in both the target company and the domestic industries.

The target company's biodiesel supply chain business processes are described in Figures 1 and 2. The business process consists of (three main areas) the supply, process and demand areas. The first areas include Fatty Acid Methyl Esther (FAME) supply and diesel fuel supply areas and other activities. FAME (B100) supplied by FAME producers and or FAME suppliers from the company's external. Diesel fuel (B0) supplied by diesel fuel producers and or suppliers from company's internal (company's fuel refinery units) and or the company's external (company's import). The second areas include such areas and activities of FAME and diesel fuel receiving, storing, blending, product handling and distributing at the company's main-fuel terminal and end-fuel terminal units. The third areas include such areas and activities of biodiesel final product) receiving, storing, handling and consuming by customers. Finally, those related data of biodiesel supply chain activities will be derived as a valuable feedback in the next supply chain activities. The blending activities takes place at fuel terminal units currently. Figure 1 and 2 describes the overall process from the input of raw products to the output and distribution of biodiesel final product.

The blending process is similar for all fuel terminal units with a certain process combination within. There are two main process schemes of FAME (B100) and diesel fuel (B0) blending process. The first scheme called inline blending which apply at fuel terminal units that have involved a new gantry system (NGS) within. The flow of process as describe in Figure 1. The second scheme called on-tank truck blending which apply at fuel terminal units that have not involved NGS yet. The flow of process as describe in Figure 2.

Inline-blending process starts with the FAME and diesel fuel supply from each product storage tanks. FAME and diesel fuel each flow to line-pipe (inline-blending) facilities through pumping units. Both FAME and diesel fuel then blended within line-pipe (inline-blending) facilities. The blended FAME and diesel fuel (biodiesel) flow to biodiesel storage tanks through pumping units. Based on customer demand, the biodiesel delivered to customers via such appropriate product transport modes. The biodiesel dispatched to customers by fuel tank trucks and other appropriate fuel transport modes. Those related data of product supply and distribution activities will be derived as valuable feedback for the next supply and distribution activities. The flow of process as describe in Figure 1. 


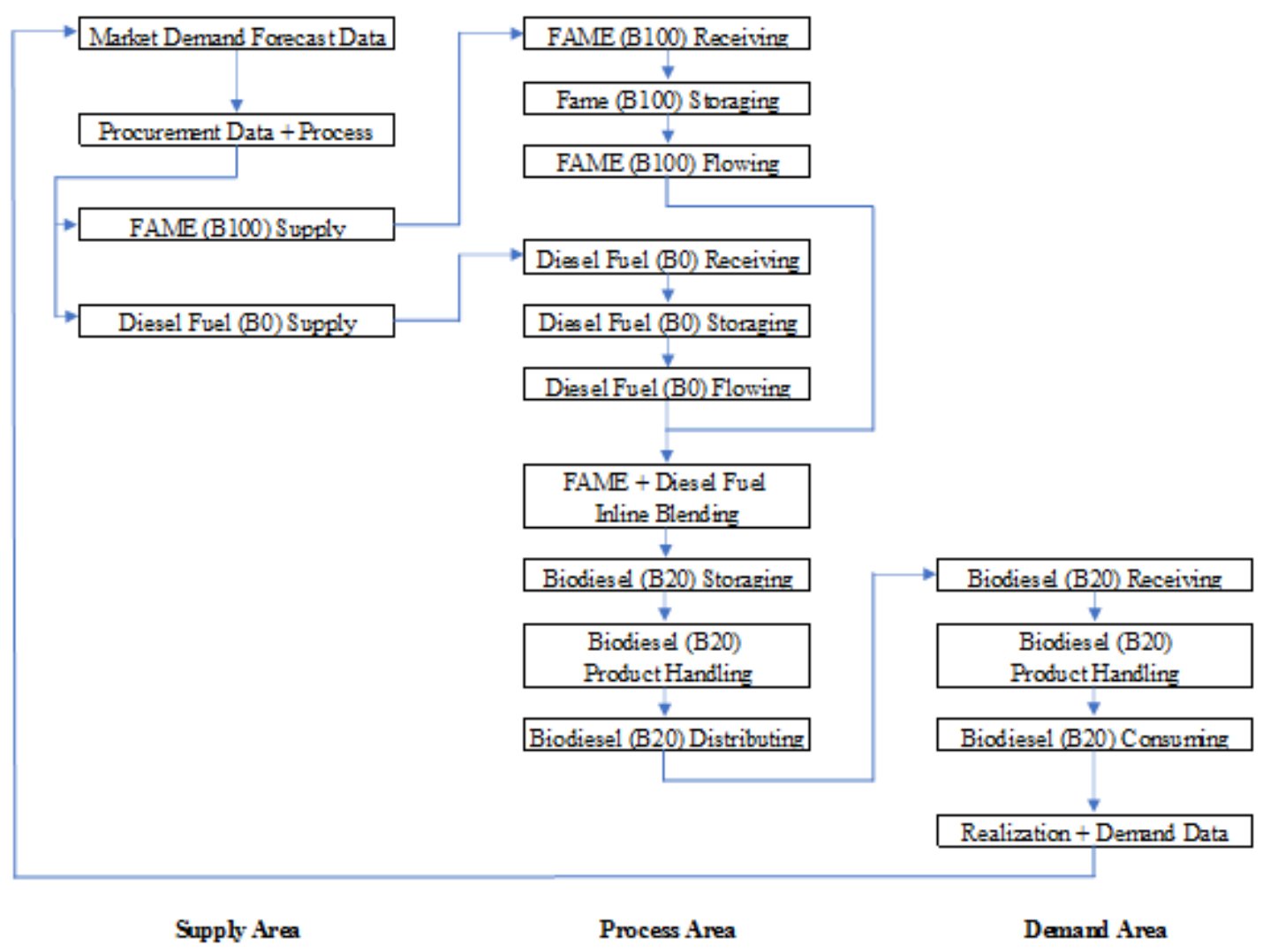

Figure 1. Biodiesel supply chain - NGS (Pertamina, 2018)

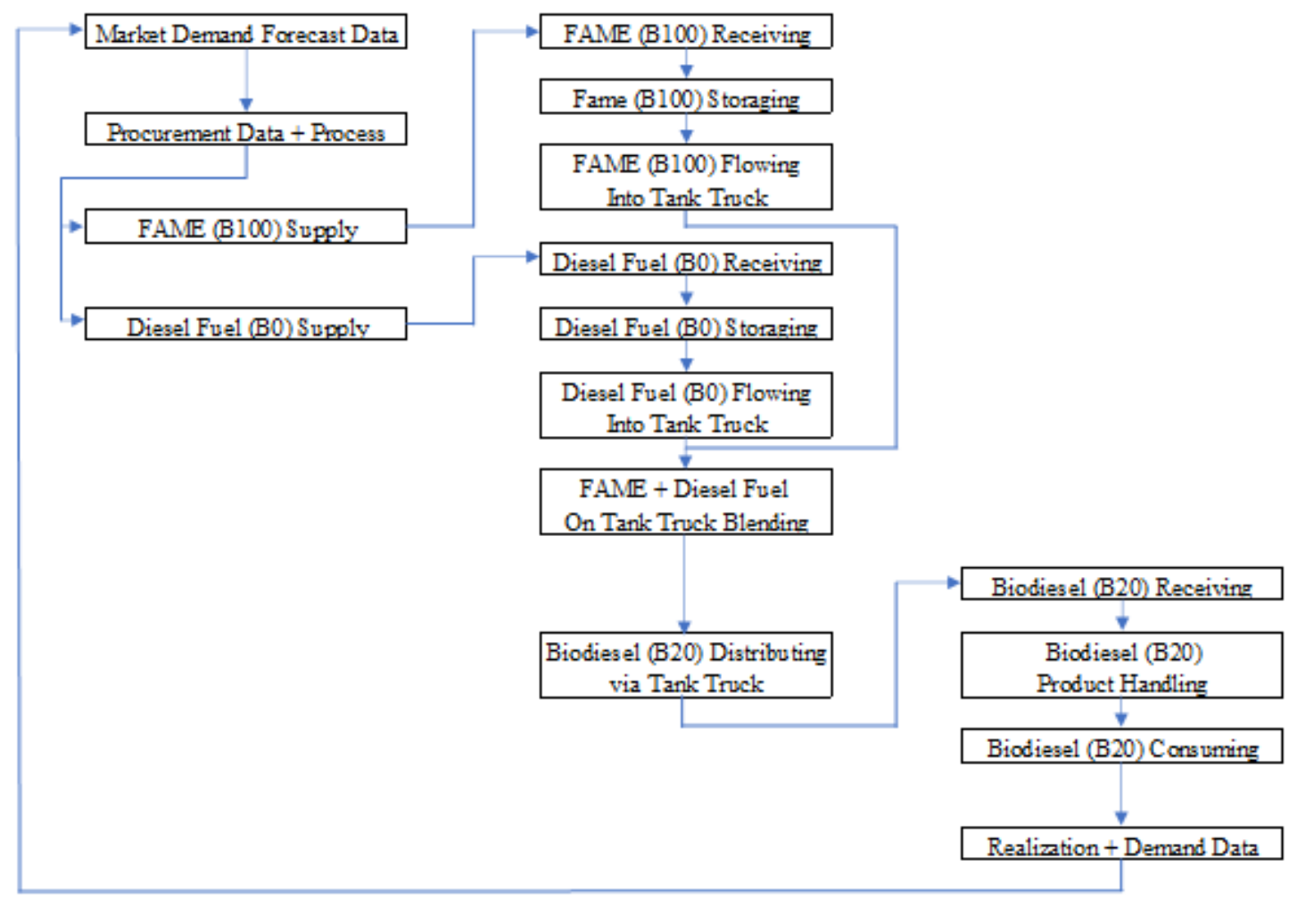

Figure 2. Biodiesel supply chain - Non NGS (Pertamina, 2018) 
On-tank truck blending process starts with the FAME and diesel fuel supply from each product storage tanks. FAME flow to FAME filling shed units. Diesel fuel flow to diesel fuel filling shed units. Both flows through pumping units. Both FAME and diesel fuel then blended within line-pipe (inline-blending) facilities. The blended FAME and diesel fuel (biodiesel) flow to biodiesel storage tanks through pumping units. Based on customer demand, the biodiesel delivered to customers via such appropriate product transport modes. Tank trucks moves to FAME filling shed units. FAME filling shed units fills the FAME into tank trucks. Then, the FAME filled tank trucks moves to diesel fuel filling shed units to get filled with diesel fuel. Both FAME and diesel fuel already filled in tank trucks. Both blended within the tank trucks. The biodiesel (blended FAME and diesel fuel) filled tank trucks then departs from fuel depot to deliver biodiesel to customers. The biodiesel dispatched to customers by fuel tank trucks. Those related data of product supply and distribution activities will be derived as valuable feedback for the next supply and distribution activities. The flow of process as describe in Figure 2.

The main differences between NGS and Non NGS operation schemes are on the content of the infrastructures and the operation systems level of automation and on the level of PICs direct involvement to both the infrastructures and the operation systems. With refer to stakeholder theory, agency theory and asymmetric information theory, the probability of occurrence of certain risks at the NGS-based and Non NGS-based operation locations will be differed one to each other. Those may conclude that there will not be any direct rule of the stakeholder's power, interest and legitimation to the related risk perception and risk priorities.

On the NGS operation scheme application, there must be a lower probability of certain risks occurrence which related to the factors of human touch, interest differences, and the asymmetric level of information among related stakeholders. In contrast, on the Non NGS operation locations, the direct human touch, interest differences, and asymmetric level of information will still be affected the operations and the risks within.

This study is the enhancement of the author's previous study in the relevant topic. Parts of the previous research results are as shown in both Table 3 and Table 4. Both tables shown that there are three highest scores of risks, i.e.: regulation risk, product arrival (delay) risk and transport facilities risk with Risk Priority Number (RPN) scores of 72 to 48 and Risk Score Value (RSV) scores of 24 to 16.

\begin{tabular}{|c|c|c|c|c|c|c|c|c|c|c|c|c|c|c|c|c|c|c|c|c|c|c|c|c|c|c|c|}
\hline \multirow{3}{*}{ Risk Types } & \multicolumn{8}{|c|}{ Probability } & \multicolumn{10}{|c|}{ Severity } & \multicolumn{9}{|c|}{ Detection } \\
\hline & \multirow{2}{*}{$\begin{array}{l}\text { Director } \\
\mathrm{H}, \mathrm{O} .\end{array}$} & \multirow{2}{*}{$\begin{array}{l}\text { VP } \\
\text { H.O. }\end{array}$} & \multirow{2}{*}{$\begin{array}{l}\text { Manager } \\
\text { Region }\end{array}$} & \multicolumn{5}{|c|}{ Fuel Terminals } & \multirow{2}{*}{\multicolumn{2}{|c|}{\begin{tabular}{|l} 
Director \\
H.O.
\end{tabular}}} & \multirow{2}{*}{$\mid \begin{array}{l}V P \\
H . O\end{array}$} & \multirow{2}{*}{$\begin{array}{l}\text { Manager } \\
\text { Region }\end{array}$} & \multicolumn{6}{|c|}{ Fuel Terminals } & & \multirow{2}{*}{$\begin{array}{l}\text { VP } \\
\text { H.O. }\end{array}$} & \multirow{2}{*}{$\begin{array}{l}\text { Manager } \\
\text { Region }\end{array}$} & \multicolumn{6}{|c|}{ Fuel Terminals } \\
\hline & & & & 1 & 2 & 3 & $4:$ & 5 & & & & & 1 & 2 & 3 & 4 & 5 & & & & & 1 & 2 & 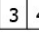 & $4: 5$ & & 6 \\
\hline \multicolumn{28}{|l|}{ Demand Risks: } \\
\hline Demand forecast inacuracy risk & 2 & 4 & 1 & 1 & 6 & 4 & 12 & 22 & 2 & 4 & 4 & 1 & 3 & 4 & 4 & 2 & 42 & 2 & 3 & 4 & 1 & 4 & 4 & 4 & 2 & 3 & 3 \\
\hline Customer lower product knowledge and higher resistance risk & 4 & 2 & 6 & 1 & 5 & 3. & $1:$ & 3 & 3 & 4 & 3 & 2 & 2 & 3 & 3 & 2 & 32 & 2 & 3 & 3 & 2 & 2 & 3 & 2 & 3 & 4 & 3 \\
\hline Customer requirements variation challenges risk & 2 & 2 & 6 & $1 \mid$ & 5 & $4 \mid$ & $2 \mid$ & $1 \mid 1$ & 1 & 4 & 2 & 2 & $2 \mid$ & $4 \mid$ & 3 & 3 & $2 \mid 2$ & 2 & 4 & 2 & 2 & 2 & $4 \mid$ & 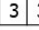 & \begin{tabular}{l|l}
3 & 2 \\
\end{tabular} & 4 & 3 \\
\hline \multicolumn{28}{|l|}{ Process Risks: } \\
\hline Product quality \& quantity discrepancy risk & 3 & 3 & 2 & 1 & 4 & 2 & 2 & 3 ( 1 & 1 & 3 & 4 & 2 & 2 & 4 & 3 & 3 & 4 这 & 4 & 3 & 3 & 2 & 2 & 3 & 2 & 3 & 3 & 3 \\
\hline Product shortage and stock out risk & 4 & 5 & 2 & 2 & 5 & 4 & 2 & 3 2 3 & 2 & 4 & 4 & 3 & 2 & 4 & 5 & 4 & 5 施 & 3 & 3 & 3 & 2 & 2 & 4. & 4. & 3 & 3 & 3 \\
\hline Product supply and distribution priority overlap risk & 4 & 5 & 3 & 4 & 5 & 2 & $2: 3$ & 3 & 3 & 4 & 4 & 3 & 4 & 4 & 3 & 4 & 35 & 3 & 3 & 3 & 2 & 4 & $4:$ & 3 & $4: 3$ & 3 & 3 \\
\hline Terminal facilities availability and reliability unfit risk & 4 & 5 & 5 & 1 & 5 & 2 & $1:$ & $3: 2$ & 1 & 4 & 4 & 4 & 4 & 4 & 3 & 2 & 5 & 3 & 3 & 3 & 2 & 2 & 4 & 2 & 3 & 4 & 2 \\
\hline Transport facilities availability and reliability unfit risk & 4 & 5 & 5 & 1 & 1 & 4 & 63 & 33 & 3 & 4 & 4 & 4 & 4 & 2 & 5 & 3 & 5 & 4 & 3 & 3 & 2 & 2 & 2 & 3 & 43 & 3 & 4 \\
\hline Hazard risk & 2 & 1 & 1 & $1 \mid$ & 2 & $5 \mid$ & 3 皮 & $3 \mid 3$ & 3 & 4 & 4 & 2 & $4 \mid$ & 2 & 4 & 5 & 5 & 3 & 3 & 4 & 2 & 4 & \begin{tabular}{|c|c|c|}
3 & 2 \\
\end{tabular} & & \begin{tabular}{l|l}
4 & 3 \\
\end{tabular} & 3 & 3 \\
\hline \multicolumn{28}{|l|}{ Supply Risks: } \\
\hline Product quality and quantity discrepancy risk & 4 & 1 & 1 & 1 & 5 & 4 & 23 & 3 & 3 & 4 & 4 & 2 & 4 & 4 & 5 & 3 & 4.5 & 4 & 3 & 3 & 2 & 3 & 3 & 3 & 3 & 1 & 3 \\
\hline Product acquisition price unfit risk & NA & NA & 2 & $\mathrm{NA}$ & 5 & 4. & 13 & $3:$ & 1 & NA & NA & 2 & NA & 4. & 3 & 3 & $4:$ & 3 & NA & NA & 2 & NA & 3 & 4. & $3:$ & 3 & 3 \\
\hline Product arrival schedule unfit risk & 4 & 4 & 1 & 5 & 4 & 4. & $3:$ & 2 & 2 & 4 & 4 & 2 & 4 & 4 & 5 & 4 & 5.5 & 4 & 3 & 3 & 3 & 3 & 3 & 4. & 43 & 3 & 3 \\
\hline Product supply sustainability challenges risk & 4 & 4 & 1 & 2 & 3 & 3. & $3: 2$ & $2:$ & 1 & 5 & 4 & 2 & 4 & 4. & 5 & 4 & 5 & 4 & 3 & 3 & 4 & 3 & 4.5 & 4. & $43^{3}$ & 3 & 3 \\
\hline Regulation challenges risk & 6 & 6 & 6 & 5 & 5 & 2 & 3 3 & 3 & 2 & 3 & 4 & 4 & 4 & 4. & 4 & $4 \mid$ & 4 (3) & 3 & 4 & 3 & 2 & 2 & 3 & & 4 & & 3 \\
\hline
\end{tabular}

Table 3. Risk scores (Wachyudi, Daryanto, Mahfud \& Arkeman, 2018)

Those describes that there are risk concern differences among stakeholder levels and locations. The higher levels of stakeholder have more concern on supply risks as their priority risks. The lower level stakeholders and locations have more concern on process risks as their priority risks. Those also proves that the level of stakeholder, location and level of information among stakeholders have a real correlation with the perception of risks among them. Those means that there is a real correlation between stakeholder levels, information levels, PIC's locations and stakeholder's perception of biodiesel supply chain risks and risk priorities. 


\begin{tabular}{|c|c|c|c|c|c|}
\hline Risk Types & Probability & Severity & Detection & RPN & RSV \\
\hline \multicolumn{6}{|l|}{ Demand Risks: } \\
\hline Demand forecast inacuracy risk & 2 & 4 & 4 & 32 & 8 \\
\hline Customer lower product knowledge and higher resistance risk & 3 & 3 & 3 & 27 & 9 \\
\hline Customer requirements variation challenges risk & 2 & 2 & 3 & 12 & 4 \\
\hline \multicolumn{6}{|l|}{ Process Risks: } \\
\hline Product quality \& quantity discrepancy risk & 2 & 4 & 3 & 24 & 8 \\
\hline Product shortage and stock out risk & 3 & 4 & 3 & 36 & 12 \\
\hline Product supply and distribution priority overlap risk & 3 & 4 & 3 & 36 & 12 \\
\hline Terminal facilities availability and reliability unfit risk & 2 & 3 & 3 & 18 & 6 \\
\hline Transport facilities availability and reliability unfit risk & 4 & 4 & 3 & 48 & 16 \\
\hline Hazard risk & 1 & 4 & 3 & 12 & 4 \\
\hline \multicolumn{6}{|l|}{ Supply Risks: } \\
\hline Product quality and quantity discrepancy risk & 1 & 4 & 3 & 12 & 4 \\
\hline Product acquisition price unfit risk & 3 & 3 & 3 & 27 & 9 \\
\hline Product arrival schedule unfit risk & 4 & 4 & 3 & 48 & 16 \\
\hline Product supply sustainability challenges risk & 3 & 4 & 4 & 48 & 12 \\
\hline Regulation challlenges risk & 6 & 4 & 3 & 72 & 24 \\
\hline
\end{tabular}

Table 4. Validated risk scores (Wachyudi et al., 2018)

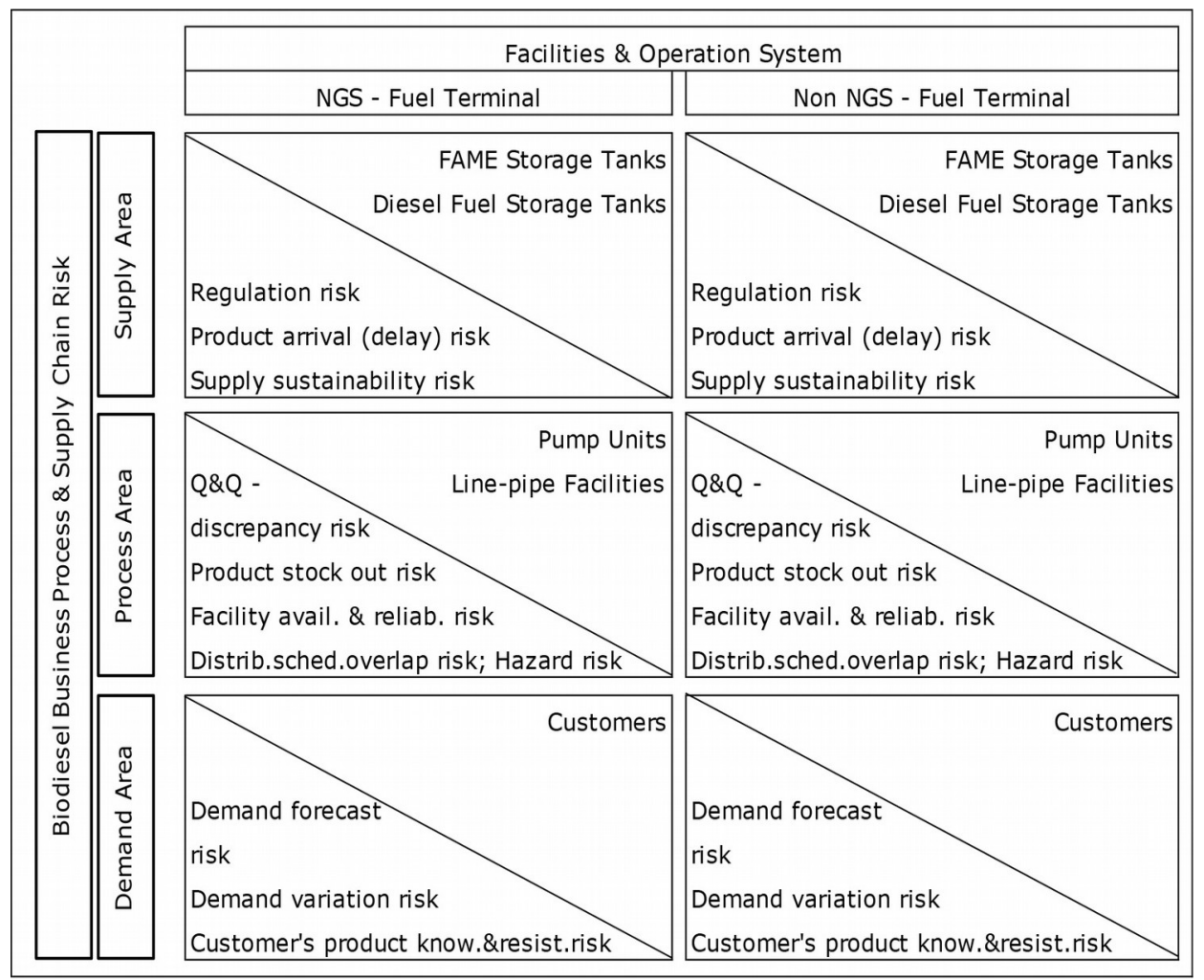

Figure 3. Biodiesel supply chain characteristic matrix - supply chain areas-based

To identify, analyze and evaluate the different risks, a Failure Mode and Effect Analysis approach applied in this study. The steps include: risk identification and classification, risk measurement and analysis, risk prioritization for mitigation. The evaluation standard based on occurrence, severity and detection aspects of each risk events. A Multiplication of these aspects will deliver a Risk Priority Number (RPN). RPN provide a level of urgency of each measured risk. The higher the RPN the higher the mitigation urgency to the risk.

Based on the analysis to the previous results, this study finds that there were three main areas of the supply chain activities, i.e.: supply area, process area and demand area. According to the two main operation schemes of fuel terminals or depots operation, those may resume that there are several clusters of risks based on both the supply chain activity areas and fuel terminals or depots operation schemes as shown in Figure 3. Even though there are 
different infrastructure types within each of supply chain activity areas, there almost no differences of risks involved within.

Figure 3 also shows that risk types existed in the areas of demand and supply are more related to the company's external challenges, so there are no differences in the supply chain characteristics both in the NGS-based and the Non-NGS based operation locations. In the area of process, though there are similar risk descriptions between NGS-based and Non-NGS based operation locations, the probability of the related risk occurrences still be differenced as above mentioned. Table 5 describes the biodiesel supply chain characteristic descriptions based on the supply chain areas of activity.

It may also conclude that the authority person behind the infrastructure and operation system related policies and practices may become a key factor to perceive and manage related risks. His or her role may involve within each of the biodiesel supply chain steps of activities. It may involve in the step of planning, organizing, actuating and even controlling of the supply chain. Off course, because of the related stakeholders or PICs interests, authority levels, information levels and even location bases differences, there will be variation of how they perceive and manage risks. Those are in-line with what the stakeholder theory, agency theory and asymmetric information theory stated. These issues are reasonable and discussable.

\begin{tabular}{|l|l|l|}
\hline \multirow{2}{*}{ Supply Chain Areas } & \multicolumn{2}{|c|}{ Fuel Terminal Operation Schemes } \\
\cline { 2 - 3 } & $\begin{array}{l}\text { New Gantry System } \\
\text { (NGS) }\end{array}$ & $\begin{array}{l}\text { Non New Gantry System } \\
\text { (Non NGS) }\end{array}$ \\
\hline Demand Area & $\begin{array}{l}\text { Risks affected by company's } \\
\text { external factors }\end{array}$ & $\begin{array}{l}\text { Risks affected by company's } \\
\text { external factors }\end{array}$ \\
\hline Process Area & $\begin{array}{l}\text { Higher automation content } \\
\text { Relatively lower treat of PICs } \\
\text { subjectivity, interest } \\
\text { differences, and information } \\
\text { levels } \\
\text { Facing similar risks with the } \\
\text { Non NGS scheme risks, but } \\
\text { still in different probability of } \\
\text { occurances }\end{array}$ & $\begin{array}{l}\text { Lower automation content } \\
\text { Relatively higher treat of } \\
\text { PICs subjectivity, interest } \\
\text { differences, and information } \\
\text { levels }\end{array}$ \\
$\begin{array}{ll}\text { Facing similar risks with the } \\
\text { NGS scheme risks, but still } \\
\text { in different probability of } \\
\text { occurances }\end{array}$ \\
\hline Supply Area & $\begin{array}{l}\text { Relatively lower treat of } \\
\text { stakeholder's power, interest } \\
\text { and legitimation } \\
\text { Risks affected by company's }\end{array}$ & $\begin{array}{l}\text { Relatively lower treat of } \\
\text { stakeholder's power, interest } \\
\text { and legitimation }\end{array}$ \\
Risks affected by company's \\
external factors
\end{tabular}

Table 5. Biodiesel supply chain characteristic descriptions - supply chain areas-based

Figure 4 describes company's biodiesel supply chain characteristics map based on related multi-perspectives. Based on the conducted interview to the related experts, there are some perspectives arise related to the biodiesel supply chain policy and activities within the target company. The study finds that there are perspectives of: organization and business types, stakeholder types, times and methods. From the perspective of organization and business types, the higher or lower levels of both business and public service obligation assignment within the organization and business will directly affect the risk types and levels faced by the company. From the perspective of stakeholder types and levels of information, the risks potentially arise will be affected by the higher or lower of stakeholder levels and information levels. From the perspective of times and methods, the potential risk types will be affected by such company dynamics within the period of times and the methods employed. Here is a specific example of this times and locations perspectives when the government decided to apply the related regulation enforcement of the biodiesel B20 implementation mandatory in the Indonesian domestic market which starting on $1^{\text {st }}$ September 2018. One of the regulation enforcements which differ from the previous regulation is on the high penalty application to whom it may concerned to apply the mandatory obligation in applying the biodiesel B20 in their business-related activities. Those findings are also relevant with stakeholder theory, agency theory and asymmetric information theory. 


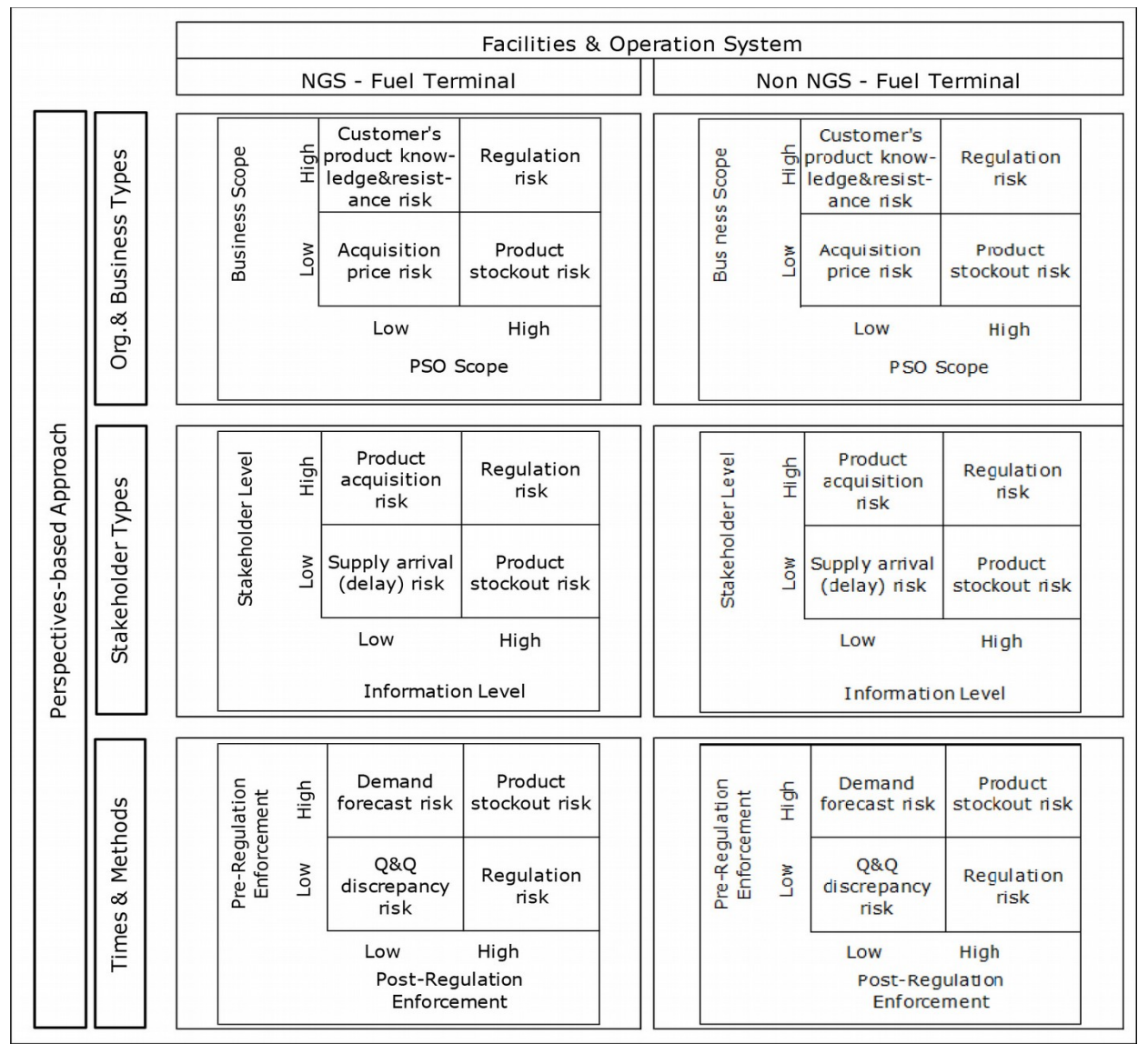

Figure 4. Biodiesel supply chain characteristic matrix - multi-perspectives-based

Table 6 describes the biodiesel supply chain characteristic descriptions based on the multi-perspectives view of the supply chain.

\begin{tabular}{|l|l|l|l}
\hline \multirow{2}{*}{ Perspectives } & \multicolumn{3}{|c}{ Fuel Terminal Operation Schemes } \\
\cline { 2 - 4 } & $\begin{array}{l}\text { New Gantry System } \\
\text { (NGS) }\end{array}$ & $\begin{array}{l}\text { Non New Gantry System } \\
\text { (Non NGS) }\end{array}$ \\
\hline $\begin{array}{l}\text { Organisation \& Business } \\
\text { Types }\end{array}$ & $\begin{array}{l}\text { Business and public service } \\
\text { obligation content levels will } \\
\text { affect company's risk types } \\
\text { and levels }\end{array}$ & $\begin{array}{l}\text { Business and public service } \\
\text { obligation content levels will } \\
\text { affect company's risk types } \\
\text { and levels }\end{array}$ \\
\hline Stakeholder Types & $\begin{array}{l}\text { Stakeholder's authorization } \\
\text { and information levels will } \\
\text { affect company's risk types } \\
\text { and levels }\end{array}$ & $\begin{array}{l}\text { Stakeholder's authorization } \\
\text { and information levels will } \\
\text { affect company's risk types } \\
\text { and levels }\end{array}$ \\
\hline Times \& Methods & $\begin{array}{l}\text { Business related dynamic } \\
\text { levels which occurred within a a } \\
\text { period of different times and } \\
\text { different methods will affect } \\
\text { company's risk types and } \\
\text { levels }\end{array}$ & $\begin{array}{l}\text { Business related dynamic } \\
\text { levels which occurred within a } \\
\text { period of different times and } \\
\text { different methods will affect } \\
\text { company's risk types and } \\
\text { levels }\end{array}$ \\
\hline
\end{tabular}

Table 6. Biodiesel supply chain characteristics descriptions - multi-perspectives-based

\subsection{Risk Mitigation Strategy}

Supply chain management decisions in the volatile business environments must consider the robustness and resiliency of the network to ensure the effective, efficient and sustainable operations. The robustness is considered at the strategic level, while the resiliency is considered at the tactical level. In fact, though the strategic level has been considered robustness of a supply chain network, the supply chain risks still exist and occur. A disruption at a supply chain network may occur at any time. 
With refer to the research results and findings, the author provides several proposed risk mitigation strategy alternatives based on the identified risks. Although the risks of regulation, product arrival (delay) and transportation facilities availability and reliability has become three risk types with the highest Risk Priority Number (RPN) and Risk Score Value (RSV), almost all-of the proposed risk mitigation strategies required collaborative schemes. Finally, those can be concluded that in order to increase the effectivity and sustainability of the company supply chain management then each of the related stakeholders could not act solely by themselves without any collaboration with others.

\subsection{Linking Business Strategy to Operation Strategy}

Slack and Lewis (2011) stated that strategic fit has a strong correlation with the fitness of organization's market requirements and operations capabilities. With refer to this context, it is interesting to link the business strategy and the operation strategy to ensure the company goal and target fulfillment through the implementation of the fittest business and operation strategies.

In-line with the energy security framework concept, the target company has its own competitive priorities in conducting biodiesel supply chain activities such as: availability, accessibility, affordability and sustainability. The corporate competitive priorities will be employed as a basis for the operation strategies framework.

To determine a supply chain strategy, there are several factors that can be considered (Ambe \& Badenhorst-Weiss, 2011). Through determining supply and demand characteristics a strategy can be chosen (Lee, 2002). To have an optimal supply chain strategy, information technology, centralized and collaborative planning, and process integration are equally important determinants (Agarwal, Shankar \& Tiwari, 2007). In terms of a long-term plans of a large amounts of money commitment, the factor of location decisions tends to be very strategic decisions (Nel \& Badenhorst-Weiss, 2010). In terms of transportation, the trade-off between the factors of responsiveness and efficiency is manifested in the choice of transport mode (Taylor, 2004). In terms of strategy types, the key enabler for an agile supply chain is the integration of business partners to enable a rapid response to changing and fragmented markets (Duarte \& Machado, 2011). Collaborative relationships among supply chain members enable different peoples and organizations to support each other by leveraging, combining and capitalizing on their complementary strengths and capabilities (Bowersox, Closs \& Cooper, 2010).

With refer to several literatures, there must be a bridge to link between business strategy and operation strategy of a company. The bridge calls as competitive priorities. Based on the energy security framework, the target company's existing biodiesel supply chain concerned points are: availability, accessibility, affordability dan sustainability. Those may be defined as the company's competitive priorities.

In the context of the supply chain areas of activity, the biodiesel supply chain related risk types include: demand risk, process risk and supply risk. The demand risks defined as risks caused by unpredictable or misunderstood customer or end-customer demand. The process risks defined as risks caused by disruptions of internal operations or processes. The supply risks defined as risks caused by any interruptions to the flow of product, whether raw material or parts, within your supply chain.

Figure 5 describes a proposed framework of the biodiesel supply chain operation strategy alternatives which based on the supply chain areas of operation and the company's competitive priorities. To fulfill the energy security target as the company's competitive priorities, each of the proposed strategy must be in-line with the target. The availability target requires a strategy which aims to ensure the fulfillment of biodiesel product availability levels both in product quantity and product quality fulfillments context. The accessibility target requires a strategy to ensure the fulfillment of biodiesel product accessibility. It may include the involvement of some related infrastructures and operation systems sufficiency to access by customers and related stakeholders. The affordability target requires a strategy for ensuring the economic and commercial affordability of the biodiesel products which customers are agreed to pay for. It may include any related efforts to ensure and to get the most competitive price levels of the product acquiring. Finally, the sustainability target requires a strategy to ensure that the product supply and distribution activities and 
contents are sustainable. It may include policies and activities for ensuring the sustainable partnership with suppliers, customers and related strategic stakeholders as well.

It may conclude that for enhancing the effectivity and the sustainability of the company's supply chain risk management each related stakeholder could not act solely by themselves without any collaborative schemes with others. Those strategies lead to collaborative strategy alternatives. In practical context, the collaborative strategy may be applied in a vary operation strategy schemes. Table 7 describes the risk mitigation strategies descriptions.

\begin{tabular}{|c|c|c|c|c|}
\hline \multirow[b]{2}{*}{ Supply Chain Areas } & \multicolumn{4}{|c|}{ Competitive Priorities } \\
\hline & Availability & Accessability & Affordability & Sustainability \\
\hline Demand Area & $\begin{array}{l}\text { Collaborative data } \\
\text { management system } \\
\text { Prod.shortage } \\
\text { and stock out risk } \\
\text { Prod.quality\&quantity } \\
\text { discrepancy risk }\end{array}$ & $\begin{array}{l}\text { Customer Held Stock, } \\
\text { Product Consignment } \\
\text { Regulat. risk } \\
\text { Pemand f'cast risk } \\
\text { prod.supply\&distribut. }\end{array}$ & $\begin{array}{l}\text { Customer Held Stock, } \\
\text { ProductConsignment, } \\
\text { Perform.-based } \\
\text { benefit/risk } \\
\text { Regulation risk } \\
\text { Product acquisitiong } \\
\text { price unfit risk }\end{array}$ & $\begin{array}{r}\text { Supplier Held Stock, } \\
\text { ProductConsignment, } \\
\text { Long-term } \\
\text { Custm'r low collaboration } \\
\text { prod.know\&resist } \\
\text { Customer requirement } \\
\text { variation challenges risk }\end{array}$ \\
\hline Process Area & $\begin{array}{l}\text { Prod.shortage } \\
\text { and stock out risk } \\
\text { Prod.quality\&quantity } \\
\text { discrepancy risk }\end{array}$ & $\begin{array}{l}\text { Regulat. risk } \\
\text { Demand f'cast risk } \\
\text { Prod.supply\&distribut. } \\
\text { priority overlap risk }\end{array}$ & $\begin{array}{l}\text { Regulation risk } \\
\text { Product acquisition } \\
\text { price unfit risk }\end{array}$ & $\begin{array}{l}\text { Product/Services SPA } \\
\text { bundling } \\
\text { Facilities availability } \\
\text { \& reliability risk }\end{array}$ \\
\hline Supply Area & $\begin{array}{l}\text { Supplier Held Stock, } \\
\text { Product Consignment } \\
\text { Prod.shortage } \\
\text { and stock out risk } \\
\text { Prod.quality\&quantity } \\
\text { discrepancy risk }\end{array}$ & $\begin{array}{l}\text { Supplier Held Stock, } \\
\text { Product Consignment } \\
\text { Regulat. risk } \\
\text { Demand f'cast risk } \\
\text { Prod.supply\&distribut. } \\
\text { priority overlap risk }\end{array}$ & $\begin{array}{r}\text { Supplier Held Stock, } \\
\text { ProductConsignment, } \\
\text { Perform.-based } \\
\text { benefit/risk } \\
\text { sharing }\end{array}$ & $\begin{array}{l}\begin{array}{r}\text { Supplier Held Stock, } \\
\text { ProductConsignment, } \\
\text { Long-term } \\
\text { collaboration }\end{array} \\
\text { Product supply sustain } \\
\text { ability risk }\end{array}$ \\
\hline
\end{tabular}

Figure 5. Biodiesel supply chain operation strategies - supply chain areas and company's competitive priorities-based (Wachyudi et al., 2018)

\begin{tabular}{|c|l|l|}
\hline No. & Steps & Descriptions \\
\hline 1 & Concept & $\begin{array}{l}\text { The potential business strategy alternative can be proposed to link with } \\
\text { operation strategy, such as: collaborative strategy. }\end{array}$ \\
\hline 3 & Mitigation Schemes & $\begin{array}{l}\text { Implement the collaborative strategy into vary operation strategies as shown in } \\
\text { Figure } 6 . \\
\text { All of the proposed strategies can be implemented and potential to lower costs } \\
\text { and higher the effectiveness of supply chain activities. } \\
\text { All of the proposed strategies potential to enhance the effectivity and the } \\
\text { sustainability of the supply chain activities. }\end{array}$ \\
$\begin{array}{l}\text { Demand risks can be mitigated through a collaborative data management } \\
\text { system between customers, suppliers and manufacturers. } \\
\text { Process risks can be mitigated through a partnership implementation, such as } \\
\text { product/ services SPA (sales and purchase agreement) bundling and service } \\
\text { level agreement (SLA). } \\
\text { Supply risks can be mitigated through an implenentation of collaborative } \\
\text { product supply scheme, such as vendor held stock, product consignment, etc. }\end{array}$
\end{tabular}

Table 7. Risk mitigation strategies description (Wachyudi et al., 2018)

\subsection{Implications}

Based on the research results and findings, here are several managerial implications to regulators, business practitioners, researchers and academicians as well. The regulators need to develop and guarantee the availability and accessibility of comprehensive, updated and valid market data and information. They also need to provide the effective and efficient regulation and bureaucracy to develop and support the more effective, efficient, and competitive national supply chain management among business practitioners and related stakeholders. 
For business practitioners, they need to start with increasing the risk know-how and awareness among related stakeholders, both internal and external the company. Furthermore, they need to develop synergy and partnership programs among corporations and related stakeholders as well, both internal and external the company in order to ensure the more effective and efficient supply chain activities application. Finally, both the corporations and the industry players have to develop and apply both supply chain risk management and enterprise risk management with the more effective, efficient, consistent and sustainable ways.

In order to enhance the research results and findings, researchers and academicians may realign those in-line with their field and expertise contexts. Academicians need to analyse, develop and spreading research activities and research results and findings in the research fields of risk, risk management, and supply chain risk management as scientific and valid references for practitioners both as regulators and business practitioners. Academicians also need to provide industrial best practice incubator medias as practical references. Furthermore, academicians need to facilitate and support both the regulators and the business practitioners in the context of policy making and standard best practice implementation at related fields.

\section{Conclusion and Recommendation}

The research results and findings show that the supply chain characteristics map can be differentiated by organisation and business types, stakeholder types, times and methods perspectives. The risk analysis finds that regulation risk, product arrival (delay) risk and transport facilities risk arise as the highest score risks and categorize as supply risks and process risk.

Collaborative strategy become a main proposed business strategy for supply areas, process areas and demand areas of the biodiesel supply chain within the target company. The mentioned strategy may apply in a vary pull and push strategies, such as: joint operation, vendor held stock, product consignment and other related strategies with both internal and external related stakeholders.

Several related recommendations were proposed based on the mentioned research results and findings. In relation with research content, there still some research limitations arise on the research population aspects. This may be a potential research area for the future research furtherly. The future research needs to involve research populations from different population areas with different population characteristics, such as outer areas, farer areas and underdeveloped areas. In the context of research perspectives, there still some potential similar topics to study on the perspectives of organisation and business types, stakeholder types, time and locations which different with this research. In the context of research methods, there will be some strategy development needs in the future. Researchers may apply inter-method combinations in either complementary or mixed approach. It possible to try multi-methods application using other analytical tools or learning tools which different with the existing applied one.

\section{Declaration of Conflicting Interests}

The authors declared no potential conflicts of interest with respect to the research, authorship, and/or publication of this article.

\section{Funding}

The authors received no financial support for the research, authorship, and/or publication of this article.

\section{References}

Agarwal, A., Shankar, R., \& Tiwari, M.K. (2007). Modeling agility of supply chains. Industrial Marketing Management, 36, 443-57. https://doi.org/10.1016/j.indmarman.2005.12.004

Ambe, I.M., \& Badenhorst-Weiss, J.A. (2011). South African automotive industry: trends and challenges in the supply chain. Journal of Contemporary Management, 8, 337-362.

Bouncken, R.B. (2011). Supply chain contingencies: The effects of up-stream directives on supplier's innovation performance. Engineering Management Journal, 23(4), 36-46. https://doi.org/10.1080/10429247.2011.11431918 
Bowersox, D.J., Closs, D.J., \& Cooper, M.B. (2010). Supply chain logistics management. (3rd ed.). Singapore: McGraw-Hill.

Carvalho, H., Maleki, M., \& Cruz-Machado, V. (2012). The links between supply chain disturbances and resilience strategies. International Journal of Agile Systems and Management, 5, 203-234.

https://doi.org/10.1504/IJASM.2012.047653

Christopher, M., \& Towill, D.R. (2000). Supply chain migration from lean and functional to agile and customized. Supply Chain Management: An International Journal, 5(4), 206-213. https://doi.org/10.1108/13598540010347334

Christopher, M. (2005). Logistics and supply chain management: creating value-adding networks. Harlow, England: Prentice Hall.

Clark, G. (2012). Understanding and reducing the risk of supply chain disruptions. Journal of Business Continuity \& Emergency Planning, 6(1), 6-12.

Defee, C.C., Williams, B., Randall, W.S., \& Thomas, R. (2010). An inventory of theory in logistics and SCM research. International Journal of Logistics Management. 21(3), 404-489. https:/ / doi.org/10.1108/09574091011089817

Duarte, S., \& Machado, V.C. (2011). Manufacturing paradigms in supply chain management. International Journal of Management Science and Engineering Management, 6(5), 328-42. https:/ /doi.org/10.1080/17509653.2011.10671181

Faisal, M.N., Banwet, D.K., \& Shankar, R. (2006). Mapping supply chains on risk and customer sensitivity dimensions. Industrial Management \& Data Systems, 106(6), 878-895. https://doi.org/10.1108/02635570610671533

Frels, R.K., \& Onwuegbuzie, A.J. (2013). Administering quantitative instruments with qualitative interviews: A mixed research approach. Journal of Counseling \& Development, 91, 184-194. https://doi.org/10.1002/j.15566676.2013.00085.x

Gurnani, H., Ray, S., \& Yunzeng, W. (2011). Special issue of production and operations management: Global supply chain risk management. Production \& Operations Management, 20, 489. https:/ / doi.org/10.1111/j.1937-

5956.2011.01242.x

Hallikas, J., Karvonen, I., Pulkkinen, U., Virolainen, V.M., \& Tuominen, M. (2004). Risk management processes in supplier networks. International Journal of Production Economics, 90(1), 47-58. https://doi.org/10.1016/j.ijpe.2004.02.007

Harland, C., Brenchley, R., \& Walker, H. (2003). Risk in supply networks. Journal of Purchasing \& Supply Management, 9(2), 51-62. https://doi.org/10.1016/S1478-4092(03)00004-9

Helo, P., \& Szekely, B. (2005). Logistics information systems an analysis of software solutions for supply chain co-ordination. Industrial Management \& Data Systems, 105(1), 5-18. https://doi.org/10.1108/02635570510575153

Jüttner, U. (2005). Supply chain risk management: understanding the business requirements from a practitioner perspective. International Journal of Logistics Management, 16(1), 120-141. https://doi.org/10.1108/09574090510617385

Lee, H.L. (2002). Aligning supply chain strategies with product uncertainties. California Management Review, 44, 105-119. https://doi.org/10.2307/41166135

Mentzer, J.T. (2001). Defining Supply Chain Management. Journal of Business Logistics, 22(2). https://doi.org/10.1002/j.2158-1592.2001.tb00001.x

Nel, J.D., \& Badenhorst-Weiss, J.A. (2010). Supply chain design: Some critical questions. Journal of Transport and Supply Chain Management, 4(1), 198-223. https://doi.org/10.4102/jtscm.v4i1.68

Nel, J.D., \& Badenhorst-Weiss, J.A. (2011). Analysing the Differences Between Theoretical and Implemented Supply Chain Strategies in Selected Organisations. Journal of Transport and Supply Chain Management. https://doi.org/10.4102/jtscm.v5i1.79

Opata, J. (2015). Strategies to Minimize the Impact of Supply Chain Risk on Business Performance [dissertation]. Minnesota (US): Walden University. 
Ouabouch, L., \& Pache, G. (2014). Risk management in the supply chain: characterization and empirical analysis. The Journal of Applied Business Research, 30(2), 329-340. https://doi.org/10.19030/jabr.v30i2.8401

Pettit, T.J., Croxton, K.L., \& Fiksel, J. (2013). Ensuring supply chain resilience: Development and implementation of an assessment tool. Journal of Business Logistics, 34(1), 46-76. https://doi.org/10.1111/jbl.12009

Pritchard, C.L. (2015). Risk Management - Concepts and Guidance (5th ed.). CRC Press. Taylor \& Francis Group.

Schotter, A., \& Thi My, H.D. (2013). The effects of the global financial crisis on supply chain members in non-BRIC emerging markets. Thunderbird International Business Review, 55, 609-618. https://doi.org/10.1002/tie.21573

Sharma, S.K., \& Bhat, A. (2011). Risk identification and assessment in supply chain. Asia Pacific Journal of Research in Business Management, 2(11), 1-2.

Slack, N., \& Lewis, M. (2011). Operation Strategy. (3rd ed.). Pearson Education. Prentice Hall.

Taylor, D.A. (2004). Supply chains. A manager's guide. USA: Pearson Education.

Tsoukas, H. (2009). A dialogical approach to the creation of new knowledge in organizations. Organization Science, 20(6), 941-57. https://doi.org/10.1287/orsc.1090.0435

Wachyudi, T., Daryanto, A., Mahfud, \& Arkeman, Y. (2018). Supply Chain Risk Mapping and Analysis: A FMEA implementation on biofuel downstream supply chain. Asian Journal of Applied Sciences, 6(6).

Wakolbinger, T.T., \& Cruz, J.M. (2011). Supply chain disruption risk management through strategic information acquisition and sharing and risk-sharing contracts. International Journal of Production Research, 49, 4063-4084. https://doi.org/10.1080/00207543.2010.501550

Wassenhove, L.N.V., \& Besiou, M. (2013). Complex problems with multiple stakeholders: how to bridge the gap between reality and OR/MS? J Bus Econ, 83, 87-97. https://doi.org/10.1007/s11573-012-0643-3

Weaver B. (2011). Coordination, Cooperation and Collaboration: Defining the C3 Framework. The Honors Program, Senior Capstone Project for Breanna Weaver.

Wieland, A., \& Wallenburg, C.M. (2012). Dealing with supply chain risks: Linking risk management practices and strategies to performance. International Journal of Physical Distribution and Logistics Management, 42, 887-905. https://doi.org/10.1108/09600031211281411

Wildgoose, N., Brennan, P., \& Thompson, S. (2012). Understanding your supply chain to reduce the risk of supply chain disruption. Journal of Business Continuity \& Emergency Planning, 6(1), 55-67.

Yao, J. (2013). Scheduling optimization of co-operator selection and task allocation in mass customization supply chain based on collaborative benefits and risks. International Journal of Production Research, 51, 2219-2239. https://doi.org/10.1080/00207543.2012.709645

Yin, R. (2012). Case study research: Design and methods (4th ed.). Thousand Oaks (CA): SAGE Publications, Inc.

Zhang L. (2013). Biofuel supply chain and bottom-up market equilibrium model for production and policy analysis. Thesis. Iowa (US): Iowa State University.

Zolkos, R. (2003). Attention to supply-chain risks grows. Business Insurance, 37(30), 4-5.

Journal of Industrial Engineering and Management, 2020 (www.jiem.org)

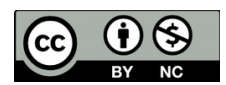

Article's contents are provided on an Attribution-Non Commercial 4.0 Creative commons International License. Readers are allowed to copy, distribute and communicate article's contents, provided the author's and Journal of Industrial Engineering and Management's names are included. It must not be used for commercial purposes. To see the complete license contents, please visit https://creativecommons.org/licenses/by-nc/4.0/. 